\title{
Barking up the right tree: Understanding local attitudes towards dogs in villages surrounding Ranomafana National Park, Madagascar can benefit applied conservation
}

\author{
Kim Valental, Joseph A. Gettinger-Larson", Colin A. \\ Chapman' and Zachary J. Farris'l!
}

\author{
Correspondence: \\ Kim Valenta \\ Department of Anthropology, McGill University \\ Montréal, Quebec H3A OG4, Canada \\ Email:valentakim@gmail.com
}

\begin{abstract}
Exotic carnivores, particularly feral and domestic dogs, represent a serious threat to Madagascar's endemic fauna. We obtained information from the local community about dogs in villages in and around Ranomafana National Park (RNP), Madagascar. Surveys were conducted ( $\mathrm{N}=359)$ to assess local opinions of dogs, reasons for owning dogs, and the willingness of dog owners to participate in spay/neuter/vaccine programs. Of surveyed individuals without dogs $(\mathrm{N}=211), 58.9 \%$ of respondents reported negative feelings towards free-roaming dogs, with only $1 \%$ of respondents identifying free-roaming dogs as a positive aspect of village life. Of individuals with dogs $(\mathrm{N}=148), 8.1 \%$ of respondents reported using their dog for hunting, and $41.2 \%$ reported that their dog had killed at least one wild animal, with $11.8 \%$ reporting that this occurred on a weekly basis. Villagers approve of spay/neuter/vaccine programs and $90.3 \%$ of respondents with dogs state they would use them if freely available. The interest in veterinary services combined with a generally negative attitude towards free-roaming dogs indicates that a spay/neuter/vaccine program would be an effective means of controlling dog populations.
\end{abstract}

\section{RÉSUMÉ}

Les carnivores exotiques, particulièrement les chiens domestiques et ceux retournés à l'état sauvage, représentent une menace sérieuse pour la faune endémique de Madagascar. Nous avons récolté des informations auprès des communautés riveraines sur les chiens vivant dans les villages et autour du Parc National de Ranomafana (RNP) au sud-est de Madagascar. Nous avons mené des enquêtes ( $\mathrm{N}=359$ ) afin d'évaluer les avis de la communauté locale sur les chiens, les raisons pour lesquelles les gens possèdent ces animaux et la volonté des propriétaires pour s'engager dans un programme de stérilisation/vaccination canine. Les villageois qui ne possédaient pas de chiens $(N=211)$ représen- taient $58,9 \%$ des personnes interrogées ; ils ont rapporté avoir des sentiments négatifs envers les chiens errants et seulement $1 \%$ des personnes interrogées ont vu un aspect positif pour la vie du village dans les chiens errants. Parmi les propriétaires de chiens ( $\mathrm{N}=148), 8,1 \%$ des personnes interrogées ont rapporté utiliser leur chien pour la chasse et $41,2 \%$ des personnes interrogées indiquent que leur chien a déjà tué au moins un animal sauvage, dont $11,8 \%$ rapportant que cela arrivait toutes les semaines. Les villageois approuvent le programme de stérilisation/vaccination canine et 90,3\% des propriétaires de chiens y auraient volontiers recours si celui-ci était gratuit et librement disponible.

\section{INTRODUCTION}

The endemic wildlife of Madagascar, particularly its diverse lemur species, are a top conservation priority due to widespread anthropogenic disturbance, including forest loss, fragmentation, bushmeat hunting, and exotic species invasion (Ganzhorn et al. 2001, Ratsimbazafy et al. 2013). Exotic carnivores, particularly feral and/or domestic dogs represent a serious threat to wildlife worldwide given their ability to act as predators, disease vectors, and to influence trophic dynamics (Barcala 2009, Vanak and Gompper 2009, Young et al. 2011, Weston and Stankowich 2013, Ritchie et al. 2014, Farris et al. 2015a). Recent research in Madagascar has highlighted the ability of these exotic carnivores to negatively affect native wildlife, including altering temporal activity patterns (Gerber et al. 2012a, Farris et al. 2015b) and spatial distribution (Farris et al. 2015c) and reducing the probability of occupancy and detection for native carnivores (Gerber et al. 2012b, Farris et al. 2015b). In addition, Farris et al. (2014) highlighted the negative interactions between exotic carnivores and lemurs (Microcebus rufus) across contiguous and fragmented forests, and point to a striking decrease in lemur occupancy at sites where exotic carni- 


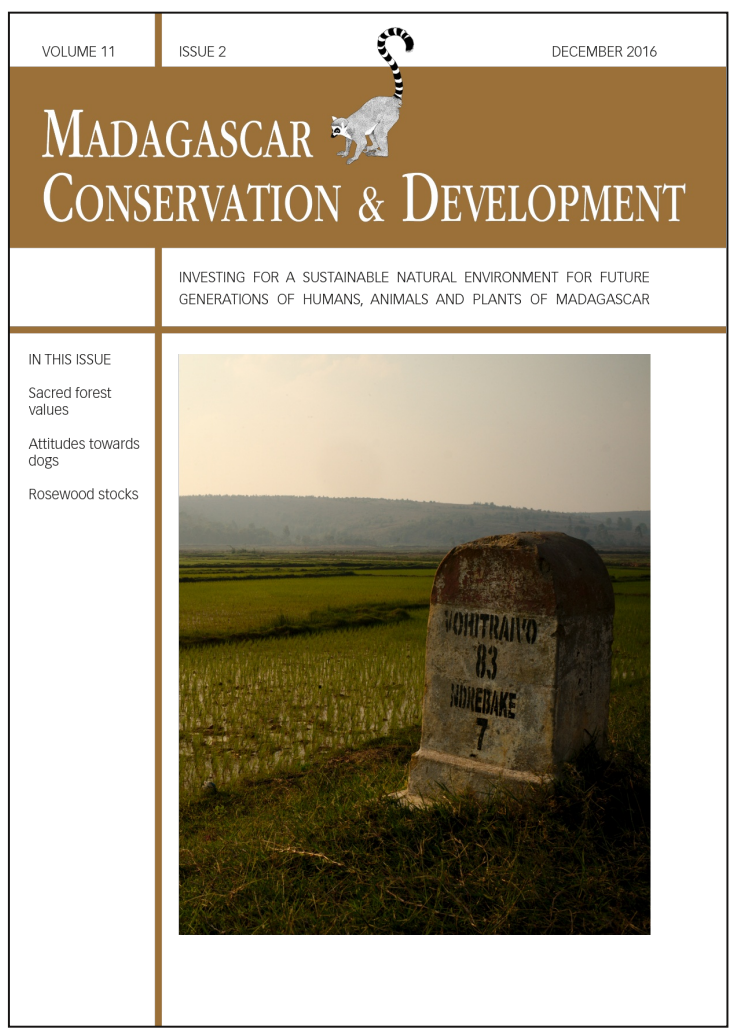

Madagascar Conservation \& Development is the journal of Indian Ocean e-Ink. It is produced under the responsibility of this institution. The views expressed in contributions to MCD are solely those of the authors and not those of the journal editors or the publisher.

All the Issues and articles are freely available at http://www.journalmcd.com

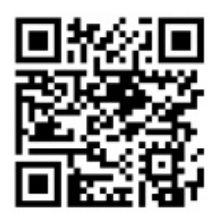

Contact Journal MCD

info@journalmcd.net for general inquiries regarding MCD funding@journalmcd.net to support the journal

Madagascar Conservation \& Development Institute and Museum of Anthropology

University of Zurich

Winterthurerstrasse 190

$\mathrm{CH}-8057$ Zurich

Switzerland

Indian Ocean e-Ink

Promoting African Publishing and Education

www.ioeink.com

Missouri Botanical Garden (MBG)

Madagascar Research and Conservation Program BP 3391

Antananarivo, 101, Madagascar 
vore presence is high. With increasing habitat fragmentation, endemic lemur populations will be simultaneously affected by increased predation and declining habitat quality. Dogs may pose a great threat to Madagascar's endemic primates as dog owners use dogs for hunting wildlife, and free-roaming and feral dogs may venture into the forest to hunt on their own. Dogs also threaten lemurs through competition interference, and may transfer zoonotic diseases to endemic primates (Butler and du Toit 2002, Butler et al. 2004, Manor and Saltz 2004, Galetti and Sazima 2006, Lenth et al. 2008, Lacerda et al. 2009, Vanak and Gompper 2009, Young et al. 2011). While many dogs that enter Madagascar's forests can be considered to be feral, i.e., unowned and unhabituated to humans, many others are owned by individuals, but are not restrained. Such dogs are a threat to the endangered lemurs and further compromise their conservation, especially when they inhabit villages within or adjacent to parks.

The goal of this study was to obtain information from the local community about feral and free-roaming dogs in villages in and around Ranomafana National Park, Madagascar, a protected area comprising $416 \mathrm{~km}^{2}$ of submontane rainforest. The park contains many threatened lemur species including the golden bamboo lemur (Hapalemur aureus), greater bamboo lemur (Prolemur simus), black and white ruffed lemur (Varecia variegata variegata), and Milne-Edwards sifakas (Propithecus diadema edwardsi). Specifically, we wanted to obtain information about (i) how many feral and free-roaming dogs there were in the area - thus the magnitude of the threat to the endemic fauna and (ii) their potential to hunt inside the national park. It should be cautioned that the information that we gathered are the impressions of the local community and contain potential sources of error or bias. Most importantly if local residents are entering the park with their dogs to obtain natural resources and know that this is an illegal activity that they should not be engaging in, they will most likely underreport it (Gavin et al. 2009). They may also know that they should not be allowing their dogs to enter the park, if there is a risk that they kill protected wildlife. As a result, responses to some of our questions should be considered as minimum estimates and we consider this bias further in the discussion.

\section{METHODS}

STUDY SITE. Surveys took place in four villages: Ambatolahy, Ambodiaviavy, Ranomafana, and Vohiparara. All villages border Ranomafana National Park (RNP), southeastern Madagascar (E $\left.047^{\circ} 20^{\prime}, S 21^{\circ} 16^{\prime}\right)$, and all villages are within five $\mathrm{km}$ of one another, along the only paved road in the region. RNP ranges in altitude from 500 to 1,500 m (Wright 1995). The rainfall varies from 2,300 to 4,000 $\mathrm{mm}$ per year, with most precipitation occurring between December and March. Average annual temperature is $21^{\circ} \mathrm{C}$, with lowest temperatures from June to September $\left(0-12^{\circ} \mathrm{C}\right)$ (Pochron et al. 2005).

METHODOLOGY. Over two-month field seasons in June 2014 and June 2015, we collected survey data by interviewing villagers. Methods used for data collection included the use of filter questions (Rennekamp and Nall 2000) to establish essential survey questions and gain focused responses, (e.g., Question 4: 'Has your dog ever killed wildlife?'; if 'Yes' go to Question 5: 'What species of wildlife has your dog killed?'; if 'No' go to Question 6). Surveys took about ten minutes to conduct and were comprised of up to 25 possible questions.
In each village, we collaborated with the village president, the village mayor and other elders, asking them to explain the goals of a free spay/neuter/vaccine initiative (www.maddoginitiative.com) to villagers and the accompanying survey questionnaires. Elders were asked to explain that free spay/neuter surgeries would be offered at the clinic, along with rabies vaccinations, de-worming, and medical treatment for sick or injured dogs. Surveys began only after receiving permission from the village president, mayor, and elders.

There were two categories of participants: (i) all dog owners who brought their dogs to the free mobile veterinary clinic providing spay/neuter/vaccine services as part of a spay/neuter/vaccine initiative to reduce feral and free-roaming dog populations were asked to participate in the survey $(\mathrm{N}=148)$. (ii) Villagers without dogs were randomly asked to participate in surveys by local team members. Surveys were administered by two Malagasy veterinary professionals in the local Malagasy dialect $(\mathrm{N}=211)$. We calculated descriptive statistics separately for individuals without dogs and individuals with dogs, since survey questions varied between these groups. Since villages were all close to one another and connected by road, we pooled all data for analyses.

All research adhered to the laws of Madagascar where the research took place, and took place under research permits issued by the Government of Madagascar and Madagascar National Parks (permit number: MIE-1594001609).

\section{RESULTS AND DISCUSSION}

Of surveyed individuals without dogs ( $N=211)$, most respondents reported generally negative feelings about the presence of freeroaming and feral dogs in their villages. $58.9 \%$ of respondents identified feral and free-roaming dogs as a problem or nuisance, $40.1 \%$ of respondents were neutral about their presence, and only $1 \%$ of respondents identified the presence of free-roaming dogs in villages as a positive aspect of village life. Similarly, $72.3 \%$ of villagers reported that life in the village would be better in the absence of feral and free-roaming dogs. In terms of the treatment of feral and free-roaming dogs, $16.5 \%$ of non-dog-owning respondents reported feeding free-roaming and feral dogs, while the remaining $83.5 \%$ reported either deterring dogs from their properties, ignoring them, or in $3.4 \%$ of cases, killing them.

Of individuals with dogs $(\mathrm{N}=148)$, the mean number of dogs per household was 1.57 (range $=1-14$, S.D. $=1.49$ ). Respondents cited personal and property protection as the number one reason for owning a dog (51.4\%), followed by a combination of companionship and protection (29.7\%). Interestingly, the remainder of respondents identified hunting as at least one of the reasons for owning a dog, either hunting alone (1.4\%) or in conjunction with protection (3.4\%), companionship (1.4\%), or both (2.0\%). As previously stated, since hunting is an illegal activity, the number of villagers that hunt with their dogs is likely higher.

In total, $6.8 \%$ of respondents reported purchasing their dogs, while the remaining $93.2 \%$ adopted dogs as strays, puppies, or offspring of previous dogs. Of those owners whose dogs produced offspring, respondents reported yearly litters in $52.4 \%$ of cases, with the remaining owners reporting litters less frequent than once per year. Respondents reported that in $45.2 \%$ of those litters, some or all of the puppies were either dead or lost. $38.1 \%$ of respondents reported giving puppies away to friends and neighbors who adopted them, yet only $2.4 \%$ of respondents reported adop- 
ting at least one of the puppies themselves. Amongst dog owners, attitudes towards ownership varied widely. While $95.9 \%$ of respondents reported feeding their dogs food scraps (primarily rice, cassava, and bones), and $35.6 \%$ of respondents reported that their dog(s) spent less than 1 hour per day away from them, $4.1 \%$ of respondents reported not feeding their $\operatorname{dog}(\mathrm{s})$, and $6.2 \%$ of respondents reported that their dog spent the entire day away (Figure 1).

In terms of dog predation on other animals, there is a strong divide in reported predation on domestic versus wild species. Only $15.8 \%$ of respondents reported that their dog had killed domestic animals, with only $4.3 \%$ of those respondents identifying domestic animal predation occurring more frequently than once a month. This finding may not be completely accurate as respondents may avoid taking ownership of responsibility of their pet killing neighbors' livestock. In $91.2 \%$ of cases where respondents reported the killing of one or more domestic animals by their dogs, these were identified as chickens and/or ducks, with one reported pig predation, and one reported dog killing.

In terms of dog predation on wild animals, numbers reported are substantially higher. In contrast to the low reported number of domestic animal predation by dogs (15.8\%), $41.2 \%$ of respondents reported that their dog had killed at least one wild animal, with $11.8 \%$ of those respondents reporting that their dog predating wild animals occurred more than once per week. Overwhelmingly, dogs were reported to prey on tenrecs (24.1\%), small, endemic insectivores of the family Tenrecidae, or tenrecs in addition to other small animals (rodents, frogs, birds, snakes $-32.7 \%$ ). $34.5 \%$ of respondents identified their dogs as killing wild rodents, frogs, birds and snakes, but not tenrecs, and $5.2 \%$ of respondents reported their dog killing introduced bushpigs (Potamochoerus larvatus). At least two dog owners reported their dogs having successfully predated fossa (Cryptoprocta ferox), Madagascar's largest native carnivore (Figure 2). While protection is the primary reason respondents report for owning dogs, $41.2 \%$ of respondents report travelling with their $\operatorname{dog}(\mathrm{s})$ into the forest adjacent to villages (i.e., RNP) at least once weekly (Figure 3).

\section{CONCLUSION}

Overall, free-roaming dogs are very much a part of the life of villagers living in and around RNP, and village surveys support previous camera trapping surveys which indicate that dogs may be predating wild animals or competitively excluding them (Gerber et al. 2012a,b; Farris et al. 2015a,b,c). However, despite the ubiquity of free-roaming and feral dogs in villages, there is generally a willingness to see dog numbers reduced or controlled, with only $1 \%$ of non-owner respondents identifying dog presence in villages as positive. Even amongst dog owners, $66 \%$ of respondents identified free-roaming dogs as a nuisance or problem, while the remaining $44 \%$ were neutral, and none expressed positive feelings towards free-roaming dogs.

In terms of both dog welfare and potentially reducing dog population numbers, villagers living in and around RNP generally approve of spay/neuter/vaccine programs and are very willing to participate in them, with $90.3 \%$ of respondents with dogs stating that they would use veterinary (including spay/neuter) services for their dogs were they freely available. Only four respondents of 145 (2.8\%) said they would not make use of free veterinary services if available. While our results do not allow us to infer the attitudes of dog owners across Madagascar, this survey may be useful as a

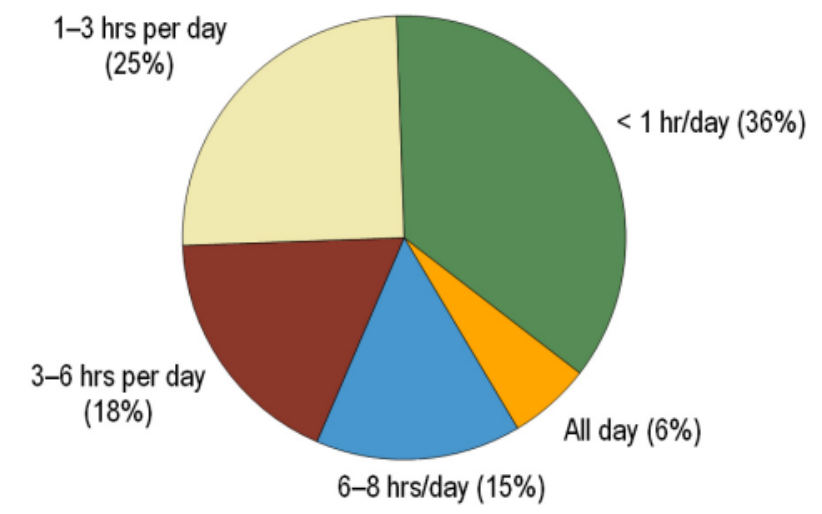

Figure 1. Reported hours per day that dogs spend away from their owners $(\mathrm{N}=145)$.

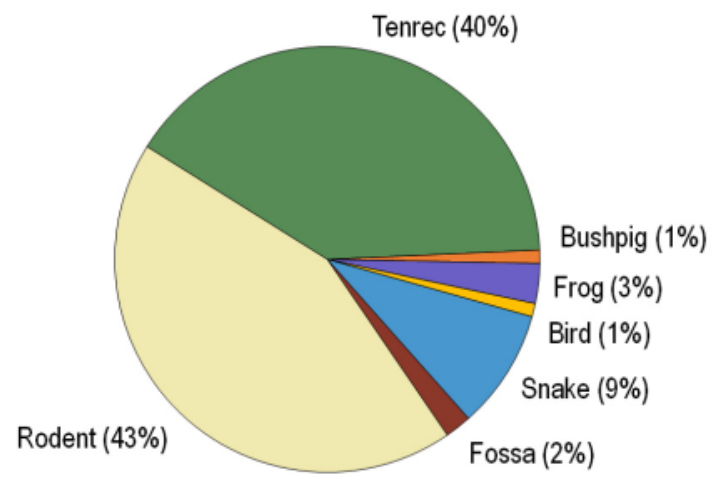

Figure 2. Reported dog predation on wild animals. Of the 58 respondents who confirmed wildlife predation by their dogs, many of these reported multiple species that were predated by dogs. This figure represents 88 reported predation events.

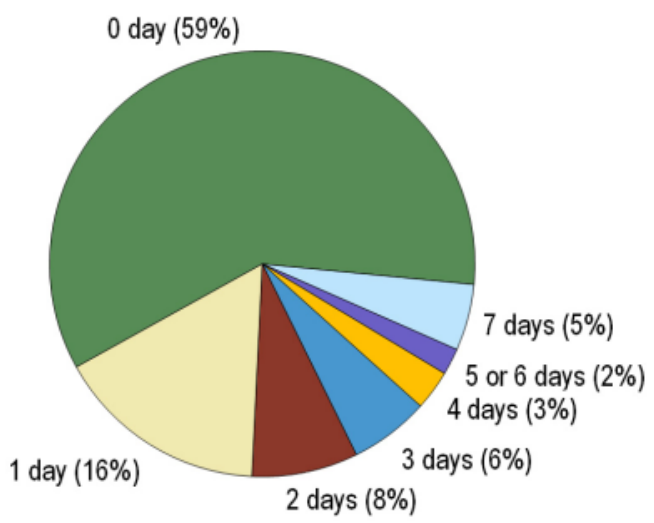

Figure 3. Number of days per week that respondents reported traveling into the forest with their dogs $(\mathrm{N}=147)$.

means of establishing the suitability and potential success of spay/neuter/vaccination programs in other areas of Madagascar.

The interest in veterinary services by the majority of respondents combined with a generally negative attitude of non-dogowners towards free-roaming dogs indicates that a spay/neuter/vaccine program in these areas should be a highly effective means of controlling dog populations. In addition, killing of local dogs by owners and non-owners is rare, suggesting capture-kill efforts would likely not be popular or seen as a viable option across this region. Thus, the way forward is likely through spay/neuter/vaccine programs, in addition to increased anti-hunting enforcement. In this region, hunting is tantamount to poaching because the wild, endemic animals are found within the 
bounds of a national park, and in many cases, are of protected species. Additionally, targeted education programs coupled with these services are necessary, given that almost half of dog-owners report traveling with their dogs into the forest. The presence of dogs within the forest has been shown to have numerous negative effects on native wildlife and the most effective measure to diminish or eliminate these effects is to curb this practice.

\section{REFERENCES}

Barcala, O. 2009. Invasive Stray and Feral Dogs Limit Fosa (Cryptoprocta ferox) Populations in Ankarafantsika National Park, Madagascar. Duke University (M.Sc. thesis), Durham. Available at <goo.gl/V70WP5>

Butler, J. R. A. and du Toit, J. T. 2002. Diet of free-ranging domestic dogs (Canis familiaris) in rural Zimbabwe: implications for wild scavengers on the periphery of wildlife reserves. Animal Conservation 5, 1: 29-37. (doi:10.1017/S136794300200104X)

Butler, J. R. A., du Toit, J. T. and Bingham, J. 2004. Free-ranging domestic dogs (Canis familiaris) as predators and prey in rural Zimbabwe: threats of competition and disease to large wild carnivores. Biological Conservation 115, 3 : 369-378. (doi:10.1016/S0006-3207(03)00152-6)

Farris Z. J., Karpanty S. M., Ratelolahy F. and Kelly, M. J. 2014. Predator-primate distribution, activity, and co-occurrence in relation to habitat and human activity across fragmented and contiguous forests in northeastern Madagascar. International Journal of Primatology 35, 5: 859-880. (doi:10.1007/s10764-014-9786-0)

Farris, Z. J., Kelly, M. J., Karpanty, S. M. and Ratelolahy, F. 2015a. Patterns of spatial co-occurrence among native and exotic carnivores in north-eastern Madagascar. Animal Conservation 19, 2: 189-198. (doi:10.1111/acv.12233)

Farris, Z. J., Gerber, B. D., Karpanty, S., Murphy, A., Andrianjakarivelo, V., et al. $2015 \mathrm{~b}$. When carnivores roam: temporal patterns and partitioning among Madagascar's native and exotic carnivores. Journal of Zoology 296, 1: 45-57. (doi:10.1111/jzo.12216)

Farris, Z. J., Golden, C. D.,.Karpanty, S. M., Murphy, A., Stauffer, D., et al. 2015c. Hunting, exotic carnivores, and habitat loss: anthropogenic effects on a native carnivore community, Madagascar. PloS ONE 10, 9: e0136456. (doi:10.1371/journal.pone.0136456)

Galetti, M. and Sazima, I. 2006. Impact of feral dogs in an urban Atlantic forest fragment in southeastern Brazil. Nature Conservation 4, 1: 146-151.

Ganzhorn, J. U., Lowry II, P. P., Schatz, G. E. and Sommer, S. 2001. The biodiversity of Madagascar: one of the world's hottest hotspots on its way out. Oryx 35,4 346-348. (doi:10.1046/j.1365-3008.2001.00201.x)

Gavin, M. C., Solomon, J. N. and Blank, S. G. Measuring and monitoring illegal use of natural resources. Conservation Biology 24, 1: 89-100. (doi:10.1111/j.1523-1739.2009.01387.x)

Gerber, B. D., Karpanty, S. M. and Randrianantenaina, J. 2012a. Activity patterns of carnivores in the rain forests of Madagascar: implications for species coexistence. Journal of Mammalogy 93, 3: 667-676. (doi:10.1644/11-MAMM-A265.1)

Gerber, B. D., Karpanty, S. M. and Randrianantenaina, J. 2012b. The impact of forest logging and fragmentation on carnivore species composition, density and occupancy in Madagascar's rainforests. Oryx 46, 3: 414-422. (doi:10.1017/S0030605311001116)

Lacerda, A. C. R., Tomas, W. M. and Marinho-Filho, J. 2009. Domestic dogs as an edge effect in the Brasillia National Park, Brazil: interactions with native mammals. Animal Conservation 12, 5: 477-487. (doi:10.1111/j.14691795.2009.00277.x)

Lenth, B. E., Knight, R. L., and Brennan, M. E. 2008. The effects of dogs on wildlife communities. Natural Areas Journal 28, 3: 218-227. (doi: 10.3375/08858608(2008)28[218:TEODOW]2.0.CO;2)

Manor, R. and Saltz, D. 2004. The impact of free-roaming dogs on gazelle kid/female ratio in a fragmented area. Biological Conservation 119, 2: 231-236. (doi:10.1016/..biocon.2003.11.005)

Pochron, S. T., Morelli, T. L., Terranova, P., Scirbona, J., Cohen, J., et al. 2005. Patterns of male scent-marking in Propithecus edwardsi of Ranomafana National Park, Madagascar. American Journal of Primatology 65, 2: 103-105. (doi:10.1002/ajp.20102)
Ratsimbazafy, J. H., Arrigo-Nelson, S. J., Dollar, L., Holmes, C. M., Irwin, M. T., et al. 2013. Conservation of Malagasy prosimians: a view from the great red island. In: Leaping Ahead. J. Masters, M. Gamba and F. Génin (eds.), pp 387-396. Springer. (doi:10.1007/978-1-4614-4511-1_43)

Rennekamp, R. A. and Nall, M. A. 2000. Using focus group in program development and evaluation. University of Kentucky, College of Agriculture, Lexington. Available at <goo.gl/YuAFj5>

Ritchie, E. G., Dickman, C. R., Letnic, M. and Vanak, A. T. 2014. Dogs as predators and trophic regulators. In: Free-Ranging Dogs and Wildlife Conservation. M. E. Gompper (ed.), pp 55-68. Oxford University Press, Oxford. (doi:10.1093/acprof:osobl/9780199663217.003.0002)

Vanak, A. T. and Gompper, M. E. 2009. Dogs Canis familiaris as carnivores: their role and function in intraguild competition. Mammal Review 39, 4: 265-283. (doi:10.1111/j.1365-2907.2009.00148.x)

Weston, M. A. and Stankowich, T. 2013. Dogs as agents of disturbance. In: Free Ranging Dogs and Wildlife Conservation. M. E. Gompper (ed.), pp 94-113. Oxford University Press, Oxford. (doi:10.1093/acprof:osobl/9780199663217.003.0004)

Wright, P. C. 1995. Demography and life history of free-ranging Propithecus diadema edwardsi in Ranomafana National Park, Madagascar. International Journal of Primatology 16: 835-854. (doi:10.1007/BF02735722)

Young, J. K., Olson, K. A., Reading, R. P., Amgalanbaatar, S. and Berger, J. 2011. Is wildlife going to the dogs? Impacts of feral and free-roaming dogs on wildlife populations. Bioscience 61, 2: 125-132. (doi:10.1525/bio.2011.61.2.7) 